\title{
Mathematical Model of Benefits and Costs of Coal Mining Environmental
}

\author{
Restu Juniah $^{1}$, Rinaldy Dalimi ${ }^{2}$, M. Suparmoko ${ }^{3} \&$ SetyoS Moersidik ${ }^{4}$ \\ ${ }^{1}$ Lecturer of Mining Engineering Department of Sriwijaya University, Indonesia \\ ${ }^{2}$ Professor and lecturer in Regional Developments Studies, Electrical Engineering, University of Indonesia, \\ Indonesia \\ ${ }^{3}$ Professor and lecturer of Environmental Economics, Budi Luhur University, Indonesia \\ ${ }^{4} \mathrm{PhD}$ and lecturer lecturer in Regional Developments, Environmental science, University of Indonesia, Indonesia \\ Correspondence: Restu Juniah, Mining Engineering Department of Sriwijaya University, Indonesia. Tel: \\ 0711-37-0178. E-mail: restu_juniah@yahoo.co.id
}

Received: September 12, 2018

Accepted: October 15, $2018 \quad$ Online Published: November 29, 2018

doi:10.5539/jsd.v11n6p246

URL: https://doi.org/10.5539/jsd.v11n6p246

\begin{abstract}
Environmental sustainability is a key issue of the coal mining sector. This is because the impact of damages on activities undertaken in this sector is deemed vulnerable to environmental sustainability. The damage that occurs has an impact on environmental unsustainability. The value of environmental sustainability is set forth in the Government Regulation No. 46 of 2017 on Environmental Economic Instruments. Under this regulation, any activity that has an impact on the environment including the coal mining sector shall assess the damage it causes. The mathematical model of environmental benefits and cost of coal mining discovered by Juniah (2013), is an expansion of the extended mathematical model of the benefits and costs of Munasinghe (1997). This model can be used and implemented to assess environmental losses and determine the value of environmental sustainability of coal mining as intended by the Government Regulation of the Republic of Indonesia. The environmental losses can be minimized by utilizing water void mine as raw water. This model can also be used by government, stakeholders, and mining investors to assess the sustainability of the coal mining environment for the resulting externalities, and the utilization of mine void water as raw water.
\end{abstract}

Keywords: enviromental services, raw water, void mine, extended mathematical model of benefits and cost of coal mining environmental sustainability

\section{Introduction}

The environment has three functions, as a provider of natural resources, as a carbon sink, and as an aesthetic giver (Juniah, 2018). Activites of forest area function by clearing forest area causing loss of hydrological function of forest area causing decrease of water carrying capacity. Land conversion activities from forest area to industrial estate, settlement, trade, waste pollution. Potential water availability that has not been optimally utilized is also a major factor that can lead to a decrease in water carrying capacity in quality, quantity and continuity (Juniah et al., 2016). Another impact arising from forest clearing activities is the ability of carbon uptake, resulting in the loss of environmental functions as carbon assimilators, the loss of the function of the beauty giver, and the loss of environmental functions as the source of the raw material. The loss of this latter function results in the depletion of natural resources.

Land clearing activities in mining are forest clearing activities, which may result in the loss of environmental functions as mentioned above. Therefore, the first important step to be taken, at the end of mining activities is the restoration of ecosystem functions, aimed at restoring environmental functions (Dallaire et al., 2015). This is because ecologically diverse forests can be drastically disrupted by coal mining activities.

Thus it becomes very important to always keep the forest area as renewable resources remain sustainable, always keeping the environment does not lose its function. Conservation of natural resources is necessary for the survival of human beings today and for future generations. This is because, environmentally sound development becomes a necessity for countries that want environmental sustainability (Juniah, 2017). Herbs as forest-formers with fauna as a natural environment, and humans as social environments, as well as mining activities as artificial 
environments have a very close relationship and can not stand alone. The destruction of the natural environment due to the activity of the built environment will have an impact on the social environment (especially the people living around the mine's circle).

Coal mining business activities provide direct and indirect benefits both economically, socially and ecologically. Direct benefits to mining companies are in the form of revenue, for governments such as taxes, and royalty as a source of state revenue and foreign exchange earners. Direct benefits in the community are the creation of new jobs, the absorption of labor in mining companies and in subcontractors of coal mining companies. Producer of raw materials for other industries, construction of facilities and infrastructure is. Other benefits as a multifier effect arising from coal mining business activities.

The opening of forest areas by open land mining coal clearing activities, as well as revegetation activities on former coal mining lands have environmental services impacts in the form of benefits and costs. Likewise, the utilization of mine void water as raw water causes the benefits and costs of raw water, giving a value of benefits for the sustainability of raw water resources.

Coal mining in Indonesia includes coal mining PT. Bukit Asam where this study was conducted, in conducting a feasibility study for the continuity of coal mining environment, only included financial benefits and costs (conventional benefits and costs), post-mining costs. The value of environmental services and the water void value of the mine for raw water have not been included in the feasibility study. The similarity is found in the Biliton Mitsubishi Alliance coal mine in Queensland Australia, only incorporating the benefits and costs of mining finance. Coal mining in Colorado only includes the cost of coal depletion (Juniah, 2013). The extended mathematical model of benefits and costs by integrating the environmental services derived from revegetation of former coal mining areas, and mine void water as raw water found in this study, can be used to determine the value of the sustainability of the coal mining environment as well as refine the mathematical model of benefits and costs previously discovered by Munasinghe (1997).

The research directly to coal mining field of PT Bukit Asam (Persero) Tbk of South Sumatera Province of Indonesia is conducted exploratory research with development model of extended net present value based on environmental service value, and mine water void as raw water. The research variables used to conduct economic assessments are the benefits and costs of economic, social and environmental aspects. The results of the study found the value of financial benefits and costs, the value of external benefits and costs of society, the value of external environmental benefits and costs arising as a result of coal mining activities. The value of environmental sustainability by including the value of environmental services of mine void water as raw water, arising from coal mining services PT Bukit Asam for 32 years for the period 1997-2023 PV 2009 amounted to IDR 67.5 Trillion. The value of the sustainability of coal mining environment prior to the inclusion of the value of mine void water environmental services as raw water is amounting to IDR 74 trillion. Based on the results of this study indicate that the use of mine void water as raw water can reduce the loss of the value of environmental services by IDR 6.5 trillion or in other words can reduce losses incurred on the environment by IDR 6.5 trillion. This research can be accomplished by the support provided by the coal mining company PT Bukit Asam (Persero) Tbk, South Sumatra Province. Unlimited thanks to PT Bukit Asam (Persero) Tbk, South Sumatera Province. References used in the writing of this paper derived from the results of previous research both published in international journals and procedural scopus indexed, indexed DOAJ, and DOI, also from the national journal in Indonesia whether accredited or not accredited, documents some coal mining companies in Indonesia and from the government (Office of Energy and Mineral Resources of South Sumatra Province).

\section{Method}

\subsection{Study Area}

Coal mining PT. Bukit Asam (PT. BA) is carried out to utilize natural coal resources in Tanjung Enim Sub-district, Muara Enim Regency, South Sumatera Province. Mining is carried out in an open-pit method with continus mining system. Tools used by Bucket Wheel Excavators (BWE), and transport by train. PT. BA's coal transportation facilities with this system are unique to PT. BA, because it is the only coal mining in Indonesia that transports this system. PT. BA was established in 1981, and on 23 December 2002 listed itself as a public company on the Indonesia Stock Exchange with PTBA code. PT. BA is the 6th largest coal mining company in Indonesia (Juniah, 2017). PT. Bukit Asam (Persero) Tbk is located at $103^{\circ} 45^{\prime} \mathrm{E}-103^{\circ} 50^{\prime} \mathrm{E}$ and $3^{\circ} 42^{\prime} 30^{\prime}$ 'S$4^{\circ} 47^{\prime} 30$ "S or longitude 9.583.200- 9.593.200 and latitude $360.600-367.000$. The research location can be reached from the city of Palembang as the capital of South Sumatra Province for approximately 4 hours by land traveling (Juniah, 2013). 


\subsection{Methodology}

The field research of environmental survey into Air Laya mine at coal mining field PT. BA, conducted to verify secondary data collected by instasional study. Instational surveys are conducted by visiting institutions related to this study. Primary data collection is done by direct observation of the impacts that arise as an externality of coal mining activities on the environment and the community, as well as distributing questionnaires as research instruments, and interviewing communities living around the PT. BA Air Laya coal mine. Population and sample research used consisted of: 1. Three blocks of PT. BA mine namely a. Air Laya Mine (ALM), b. Bangko Barat Mine (BBM), Muara Tiga Besar Mine (MTB) as a research population, and ALM block as a research sample; 2. People living around PT. BA TAL coal mining as research populations, people who are directly affected and live in downstream section of PT. BA as research sample.

The sample is determined by purposive sampling based on considerations: (1) On how long the PT. BA mining blocks have been mined and reclaimed; sought for blocks that have been mined and reclaimed for a long time, so that the effects of the impacts of the activity on the environment can be identified; (2) Communities living downstream affected by the direct impact distribution of PT. BA ALM activities. This type of research is exploratory research by developing the mathematical equations of the extended model of benefits and Munasinghe costs. The analytical method uses descriptive analysis of externalities arising from the existence of coal mining activities on the value of environmental services, and mine void water as raw water in the form of benefits and costs (2017).

\section{Results}

Environmental damage can destroy civilization. Therefore, the hope for the sustainability of a civilization is a sustainable environment. Civilization was built using mining commodities. Likewise, the necessities of life such as houses, high-rise buildings, motorized vehicles, mobile phones, electronic equipment, home appliances, office equipment, etc. were filled with mining commodities. Mining commodities are obtained through mining activities (Juniah, 2018).

Mining openly raises externalities. Externalities in this study arise as a result of open pit coal mining. Externalities cause benefits and costs due to the loss and recovery of the value of environmental services, and the use of voids as raw water.

\subsection{Open Pit Mining Activities}

Mining system in open pit is done by: (1) Open pit system/open cut/open cast; (2) Strip mining; (3) Alluvial mining; and (4) Quarry system. Open pit/open cast/open cut system in Indonesia is widely applied to mineral mining such as gold mine in PT Amman Mineral, copper ore mine in PT Freeport Indonesia, Nickel mine in PT Valey Indonesia, while coal mining using strip mining system such as PT Bukit Asam (Persero) Tbk South Sumatera Province, PT Kaltim Prima Coal South Kalimantan Province, PT Adaro Indonesia Province South Kalimantan (Juniah, 2003), PT Buana Eltra (Endarto et al., 2018). Alluvial mining systems for alluvial deposits such as tin ore mines at PT Timah Bangka, and quarry systems usually used for limestone mining, such as those in PT Semen Padang West Sumatra Province (Toha et.al, 2017), limestone mining in England (Legwaila et al, 2015; Eugene, LR \& Singh, 2014).

The stages of open coal mining are as follows:

1) Mining land/forest area clearing activities, namely land clearing, stripping, top soil, and overburden, coal exploitation activities (excavation, loading and transportation of coal).

2) Mining reclamation activities and coal mining.

\subsection{Extended Model Benefits and Environmental Sustainability Costs of Coal Mining}

The ironic and dilemmatic conditions in the mining sector are due to economic benefits arising from mining activities, with negative impacts that are hard to ignore. This is the first thought that arises to develop an extended model of benefits and costs by integrating the value of environmental services, and mine void water as raw water due to its existence. Wise attitude is needed to overcome the above conditions, so that the benefits of the mining sector and the interests of environmental protection can go hand in hand and harmoniously. The results of a literature review review of previous research found that there were positive and negative externalities of coal mining openly (during the life of mine and coal mining) to the value of environmental services, and mine void water for raw water in the form of benefits and costs as shown in The conceptual framework on figures 1 (Juniah, 2013). 


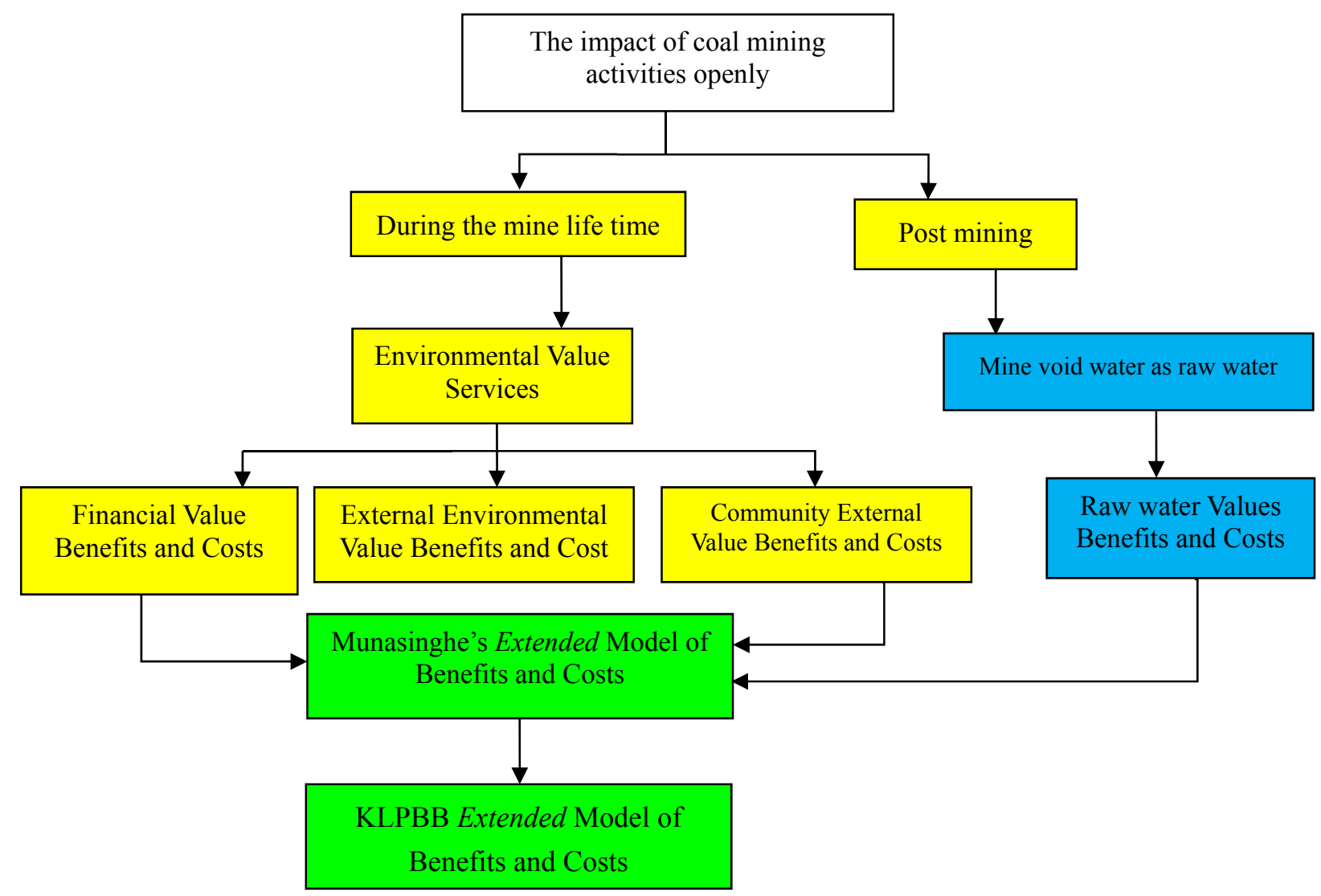

Figure 1. The Conceptual framework

Source: Juniah, 2013

Forests do not vegetate due to land clearing activities of coal mining cause loss of environmental function, and result in the depletion of natural resources and environmental degradation. The loss of environmental functions also resulted in the loss of clean air availability as happened in the Mountaintop coal mine in West Virginia, which caused the loss of environmental benefits for the applachian community to obtain clean air. Its continued impact is the public health impairment of Appalachia, which lives around the Mountaintop coal mine, and raises external costs in the Appalachia community. The multiflier effect of open coal mining activities in The Bowen Basin in Queensland, PT. Kaltim Prima Coal, PT. INCO, and PT. Freeport Indonesia are examples of positive externalities in mining activities arising in the community. Positive externalities are arised in the form of external costs and benefits.

Environmental external costs and benefits are also generated from revegetation activities on former PT. Indominco Mandiri coal mine land in Indonesia's protected forests. Monitoring of mine void water as raw water also raises the costs and benefits of raw water. Utilization of mine void water as raw water can restore the environmental function as a provider of raw water resources lost due to acidity of acid mine water.

The conventional benefit and cost model or Net Present Value (NPV) which contains the benefits and financial costs of cash flow income is a mathematical equation model that has been given (Peter, 1980). The mathematical equations of this conventional cost and benefit model are used in Indonesia coal mining, and Australian coal mining Biliton Mitsubihi in Western Australia (Robin at.al, 2003). Munasinghe (1992) extends this already given benefit and cost model by including the benefits and costs of environmental aspects so that it becomes a mathematical equation of the benefits model and the expanded costs (extended benefits and Munasinghe costs). Sudirman's research (2011) uses the extended equation of benefits and Munasinghe costs to determine the benefits and costs of missing and recovering the value of environmental services as an externality of PT. Indominco's coal mining in Indonesia's protected forests. The expansion of the mathematical equation of the extended model of Munasinghe benefits and costs by including the value of environmental services, and mine 
void water as raw water is a unified concept that complements the shortcomings of previous research, and becomes the state of the art of this research. The general mathematical equation of the benefits and costs of ESCM is found to be the novelty of this study.

\section{Discussion}

4.1 Identification of Components of Benefits and Costs of Environmental Services Value, and Void Mine Water as Raw Water for Extended Models of Environmental Sustainability of Coal Mining (ESCM) Benefits and Costs

Measures undertaken to identify beneficiary and cost components of environmental services value, mine void water as raw water for extended model of ESCM benefit and cost as follows:

Step 1. Make observations at the ALM coal mining location PT. BA to get facts and data related to the impact arising from ALM activities of PT. BA on the environment and society especially those who live in the downstream areas who are directly affected.

Step 2. Identify negative and positive externalities as a result of PT.BA ALM coal mining on the loss and recovery of environmental services, and mine water voids as raw water in the form of external financial benefits and costs, environmental benefits and costs, external benefits and costs, benefits and costs of raw water.

\subsubsection{Financial Benefit And Cost}

Financial impact arising from the financial benefits and costs as presented in Table 1.

Table 1. Financial benefit and cost of ALM PT. BA

\begin{tabular}{lllccl}
\hline \multirow{2}{*}{ No } & \multirow{2}{*}{$\begin{array}{c}\text { Financial Benefit and Cost } \\
\text { Components }\end{array}$} & \multicolumn{2}{c}{ Contribution of ALM PT. BA } & \multirow{2}{*}{$\begin{array}{c}\text { Benefit and Cost } \\
\text { Categories }\end{array}$} \\
\cline { 3 - 5 } & \multicolumn{1}{c}{ Sum } & Unit & Period & Financial Benefits \\
\hline 1 & Coal Selling $\left(\mathrm{B}_{\mathrm{d}}\right)$ & 26,802 & IDR billion & $1997-2009$ & Finals \\
2 & Coal Production Cost $\left(\mathrm{C}_{\mathrm{d}}\right)$ & 5,107 & IDR billion & $1997-2009$ & Financial Costs \\
3 & PT.BA corporate income & 4,09 & IDR billion & $1997-2009$ & Financial Benefits \\
4 & Royalties, Taxes, Non Taxes & 5,031 & IDR billion & $1997-2009$ & Financial Costs \\
5 & Shareholder income & 2,043 & IDR billion & $2003-2008$ & Financial Costs \\
6 & Contribution in the railway sector & 4.867 .264 & IDR million & $1997-2009$ & Financial Costs \\
\hline
\end{tabular}

Source: Juniah, 2013

Financial benefits and costs due to the environmental services are as follows:

1) The financial benefits of the value of coal sales $\left(B_{d}\right)$ are the direct benefits of coal sales as environmental services of coal natural resource providers.

2) The financial cost of the production $\operatorname{cost}\left(\mathrm{C}_{\mathrm{d}}\right)$ is either directly or indirectly incurred, which consists of the following cost components:

- Royalty fees, tax fees, non-tax fees are indirect costs which are external benefits as indirect impacts coal mining activities against the government

- General and administrative costs (employee salaries, production services etc.)

- Depreciation costs

- Transpostation costs

\subsubsection{External Environmental Benefits and Costs}

Positive external forest areas by mining activities or do not give value to external economic benefits. These benefits include the economic value of carbon, and negative external value of forest costs (external costs). The value of carbon economic benefits from non-mining forest areas was found by Betani et al (2016) amounting to US \$ 419,787.6 or Rp 5,635,648,530 as economic benefits of forest carbon for Bukit Suligi training for Special Purpose Forest Area. Agung (2016) found the average economic value of carbon uptake in trees on the surface, 
for forest area of 31,883.4 ha (Study Area in Kecamatan Keliling Lake, Kerinci Regency) of Rp 3,720,854 x 106 / year. The economic value of integrated post-mining space utilization of PT Bukit Asam South Sumatra until the closure of the coal mine in 2043 uses anaisis benefits and costs of USD 91,295,530 (Kodir et al, 2017)

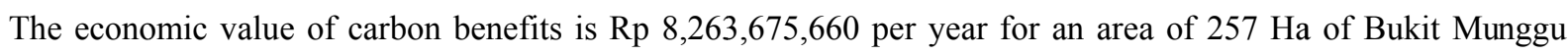
primary forest obtained from the PT Bukit Asam Coal Mining Business Area, South Sumatra Province (Rahmaputri, 2014). Economic Value of Carbon stored in protected forests is IDR 59,322,710,000 (Yusuf et.al, 2010).

Negative externality due to forest clearing activities in the Osmington Western Australia coal mine have an impact on the environment, in Applachia West Virginia causing water pollution, air pollution, decreased number of plants, and changes in landscape (Juniah, 2013). The impact of coal mining activities at the ALM PT. BA, Mountaintop locations in West Virginia, and the Wilpinjong coal mining are shown in Figure 2.

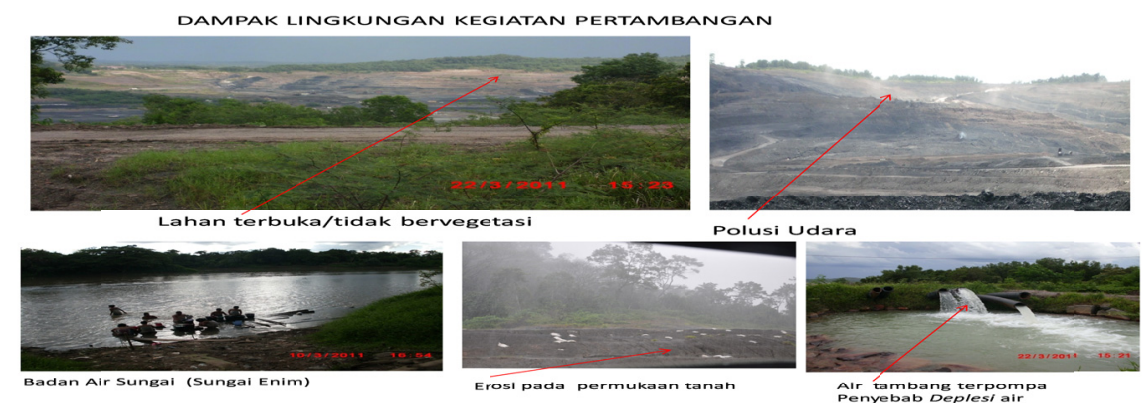

a. Coal mining location of ALM PT. BA

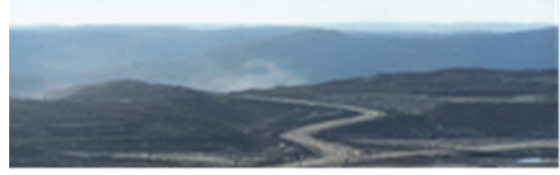

b. Mountaintop Coal Mining

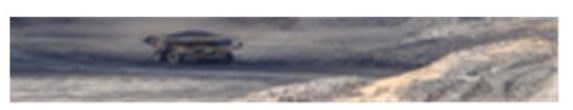

c. Coal Mining Wilpinjong NSW West Virginia

Figure 2. Environmental Impact of Coal Mining

Source: Juniah, 2013.

Negative externalities to the environment cause external environmental costs (Ce), as costs incurred on the environment due to the loss of the value of environmental services due to forest area opening activities. External environmental costs $(\mathrm{Ce})$ consist of:

a. Wood depletion due to loss of forest environmental services as a provider of timber resources.

b. Carbon is released due to the loss of forest environmental services as a carbon sink.

c. Erosion retention due to loss of forest environmental services as an erosion barrier.

d. Coal depletion is a direct cost that arises from the environment due to the loss of forest environmental services as a provider of raw materials.

Revegetation activities of former coal mining lands have external environmental (Be) benefits, namely environmental benefits that arise as an externality of coal mining activities to the environment. Environmental benefits $(\mathrm{Be})$ consist of the following components:

1) Carbon is absorbed due to the recovery of forest environmental services to absorb carbon.

2) Recovery of erosion retention due to the recovery of forest environmental services to withstand erosion.

3) Timber is planted as a benefit for the environment due to the recovery of forest environmental services to provide natural timber resources.

\subsubsection{Community External Benefits and Costs}

Disruption to the health of people living around coal mining arises due to the loss of environmental services of forest areas as carbon sinks. This disturbance results in external costs in the community. Mountaintop mining in West Virginia causes disruption to the health of people living around Appalachia due to air pollution. Air 
pollution occurs due to loss of environmental services as a provider of clean air. Air pollution occurs during the activities of extracting, loading and transporting coal, processing coal (Juniah, 2013).

The contamination of the Santan River in the coal mining area of PT Indominco Mandiri raises external costs in the community because the community cannot obtain raw water (Sudirman, 2011). The external costs of society $\left(\mathrm{C}_{\mathrm{em}}\right)$ consist of:

a. Public health costs $\left(\mathrm{C}_{\mathrm{em} 1}\right)$ due to loss of environmental function as a provider of clean air for the community.

b. Domestic water costs $\left(\mathrm{C}_{\mathrm{em} 2}\right)$ due to loss of environmental function as a provider of raw water for the community.

c. The loss of community income due to the loss of environmental functions as a provider of livelihoods for the people of the planters who released their gardens for coal mining activities

The value of external benefits in the community $\left(B_{e m}\right)$ is settles around coal mining such as the increase in incomes of the community. This benefit as a positive externality of coal mining activities created from income in the community through multiflier coal mining effects, such as employment absorption, the creation of new business opportunities in the community (Juniah, 2013). The external benefits and costs of people living around ALM PT. BA coal mining are shown in Table 2.

Table 2. Community external benefits and costs at ALM PT. BA Coal mining site

\begin{tabular}{|c|c|c|c|c|c|}
\hline \multirow{2}{*}{ No } & \multirow{2}{*}{$\begin{array}{l}\text { Components of Community } \\
\text { Benefits and External Costs }\end{array}$} & \multicolumn{3}{|c|}{ Contribution of ALM PT. BA } & \multirow{2}{*}{$\begin{array}{c}\text { External Benefit and Cost } \\
\text { Categories }\end{array}$} \\
\hline & & Sum & Unit & Period & \\
\hline 1 & PT. BA Established Partners & 31,309 & Unit & 2004-2010 & External benefits of society \\
\hline 2 & CSR Assistance of PT. BA & 170,08 & $\begin{array}{l}\text { IDR } \\
\text { billion }\end{array}$ & 2006-2010 & External benefits of society \\
\hline 3 & Employment absorption & 14,280 & person & 2011 & External benefits of society \\
\hline \multirow[t]{2}{*}{4} & New business opportunities: & & & & External benefits of society \\
\hline & $\begin{array}{l}\text { Breeding/Nursery business, } \\
\text { Bokashi fertilizer business, } \\
\text { handicrafts from used tire } \\
\text { conveyor belts }\end{array}$ & & & $\Rightarrow=$ & \\
\hline 5 & Public health disorders $\left(\mathrm{C}_{\mathrm{em} 1}\right)$ & & & & External community costs \\
\hline 6 & Domestic water $\mathrm{C}_{\mathrm{em} 2}$ ) & & & & External community costs \\
\hline 7 & $\begin{array}{l}\text { Loss of community income } \\
\left(\mathrm{C}_{\mathrm{em} 3}\right)\end{array}$ & & & & External community costs \\
\hline 8 & Community Income $\left(\mathrm{B}_{\mathrm{em}}\right)$ & & & & External benefits of society \\
\hline
\end{tabular}

Source: Juniah, 2013

\subsubsection{Benefits and Costs of Environmental Services for Mine Void Water for Raw Water}

Void water in some Indonesian coal mines tends to have low acidity with $\mathrm{pH}<4$ (Juniah, 2013). Mine void water utilization for raw water provides economic and ecological benefits directly and indirectly for the sustainability of water resources and the mining environment. Direct and indirect economic benefits are obtained from the utilization of mine void water in several Indonesian coal mines such as at PT Adaro Indonesia, PT Multi Harapan Utama. This economic assessment of the benefits obtained by Diwyastra et al., 2015 towards PT Multi Harapan Utama, and (Moersidik et al, 2014) towards PT Adaro for the sustainability of water resources, for freshwater 
aquaculture. Moersidik et al (2014) and Juniah (2013) found a model for sustainability of water resources by utilizing mine void water for freshwater and raw water cultivation. Curtis J.et.al (2009) found an economic benefit for the city of Greenwood, Arkansas if it could use water from coal mining in Arkansas for raw water.

Utilization of mine void water for raw water in PT Adaro Indonesia's coal mining besides generating benefits and costs for raw water. The benefits arising aside from coal mining companies and communities living around the mine, as well as maintaining raw water resources remain sustainable for the mining environment of PT Adaro Indonesia. The immediate benefits that arise in the form of raw water benefits $\left(\mathrm{B}_{\mathrm{av}}\right)$, is an environmental service as a provider of raw water resources. Benefits obtained from the activities of utilizing mine void water for raw water not only during the mine life as well as coal production activities, but also in the post-mining coal so that raw water resources can be maintained sustainably. The cost of raw water $\left(\mathrm{C}_{\mathrm{av}}\right)$ arising as a direct cost of the void mine water management as raw water.

Mine voids and utilization of mine voids as raw water are shown in Figure 3.
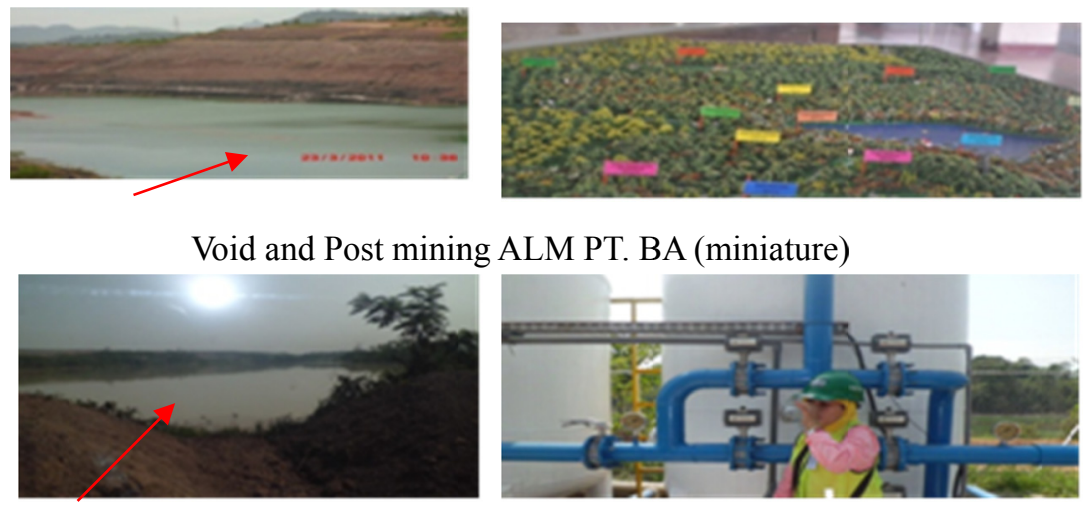

Mine Void Adaro

Utilization of Void mine water

as raw water PT Adaro Indonesia

Figure 3. Mine Void, and utilization of mine void water as raw water

Source: Juniah, 2013

Step 3. Identify components of benefits and costs of environmental services, and mine void water as raw water to find general models of extended benefits and costs of ESCM

Based on the identification made in step 2 of the positive and negative externalities arising from coal mining activities resulting in the disappearance and recovery of environmental services, and mine void water, identifiable components of environmental service benefits and costs, and mine void water as raw water for the general extended model benefits and expenses ESCM as follows:

1) Coal sale $\left(B_{d}\right)$ is a financial benefit from coal mining activities because of the environmental function as a coal natural resource provider.

2) External environmental benefits $\left(B_{e}\right)$ arising from the recovery of environmental services through revegetation activities in the form of:

a. Carbon absorbed as an external environmental benefit due to the recovery of environmental services as carbon sinks.

b. Recovery of erosion protection as an external benefit of the environment due to the recovery of environmental services as erosion protection.

c. Timber grown as a direct benefit to the environment due to the recovery of the value of environmental services to provide the timber's natural resources.

3) Increased community income $\left(B_{e m}\right)$ is a benefit that arises in the community created from income in the community through multiflier effects of coal mining such as labor absorption, the creation of new business opportunities in the community (entrepreneurs).

4) Increase in income of post-mining coal communities $\left(B_{\text {empc }}\right)$ as external benefits generated from revenues in post-mining coal communities with water void utilization of mine for raw water as environmental services as providers of raw water resources 
5) Benefits of $\left(\mathrm{B}_{\mathrm{av}}\right)$ raw water as a direct benefit arising from the utilization of mine void water for raw water as an environmental service as a provider of raw water resources

6) Environmental external costs $\left(\mathrm{C}_{\mathrm{e}}\right)$ as costs incurred to the environment due to loss of environmental services due to forest clearing activities.

a. Wood depletion as an environmental cost due to loss of forest ecosystem services as a provider of woods.

b. Carbon is regarded as an external cost incurred to the environment due to loss of forest environmental services as a carbon sink.

c. Anchoring erosion as an external cost arising from the environment due to loss of forest ecosystem services as an erosion barrier.

7) Coal depletion is an external cost arising from the environment due to the loss of forest environmental services as a provider of coal resources.

8) Community external costs $\left(\mathrm{C}_{\mathrm{em}}\right)$ are costs incurred in the community as an externality of coal mining activities to the community due to the loss of environmental benefits for the community due to forest area opening activities.

a. Costs arising from the loss of forest environmental services as a provider of clean air for the community as a cost of disruption to public health $\left(\mathrm{C}_{\mathrm{em} 1}\right)$ as

b. Costs arising from the loss of forest environmental services as a provider of raw water for the community as domestic water supply $\left(\mathrm{C}_{\mathrm{em} 2}\right)$.

c. Community external costs due to the loss of forest environmental services as a source of livelihood for the community of planters who release their gardens for coal mining activities as a cost of loss of community income.

9) Production costs $(\mathrm{Cd})$ are costs incurred against the company due to the loss of environmental services as a provider of coal natural resources due to coal exploitation activities.

10) The cost of raw water (Cav) is the direct costs incurred to manage mine void water for raw water because of the loss of environmental functions as a provider of raw water resources.

The result of the identification of the benefit value components and the above costs required to build the general model of extended benefits and costs of ESCM found in this study has responded to the first objective of the study.

\subsection{Mathematical Model Of Extended Benefits And Sustainability Costs Of Coal Mining Environment By Including The Value Of Mine Void Water Environmental Services As Raw Water}

The paradigm of sustainable mining development in the mining sector requires the development of the 3 pillars of sustainability, those are economic, social, and environment for the life of the mine and coal mining for the sustainability of the coal mining environment. This is because the goals and means of balancing economic, social and environmental pillars in the mining sector are sustainable mining (Kokko et.al, 2015). Sustainable mining can only be realized if the conditions for aspects of sustainable development can be met. This prerequisite is the basis for the need to expand the equation of extended benefits and costs that existed previously, by building a model of equality of extended benefits and costs for ESCM. The extended model of benefits and costs for ESCM resulting from this study is built from the conventional equality of benefits and costs that have been given and has been expanded by Munasinghe (1992) in Suparmoko 2006. Conventional cost and benefit mathematical equations are equations that have been given with benefit variables and variables the costs in it, as Munasinghe has done before, what can be done about the mathematical equation of the benefits and costs given are only to expand the components of the benefits and costs. So, do not add or subtract by entering new variables outside the benefit and cost variables. Munasinghe in Suparmoko (2006) extends the conventional benefits and costs by including the external benefits and costs of environmental aspects so that the mathematical equation of the conventional benefit and cost model becomes a mathematical equation of the extended model of benefits and costs. The expansion of the mathematical equation of the extended model of benefits and costs in this study is carried out by incorporating environmental services, and coal mine void water as raw water into the extended model of benefits and costs of Munasinghe (Extended $\mathrm{NPV}_{\mathrm{ms}}$ ).

Mathematical equations of extended benefits and Munasinghe costs: 


$$
\text { Extended } N P V_{m s}=\sum_{t=0}^{T} \frac{\left(B_{d}+B_{e}\right)}{(1+r)^{t}}-\sum_{t=0}^{n} \frac{\left(C_{d}+C_{p}+C_{e}\right)}{(1+r)^{t}}=\sum_{t=0}^{T} \frac{\left(B_{s m}+C_{s m}\right)}{(1+r)^{t}}
$$

Source: Suparmoko (2006)

where:

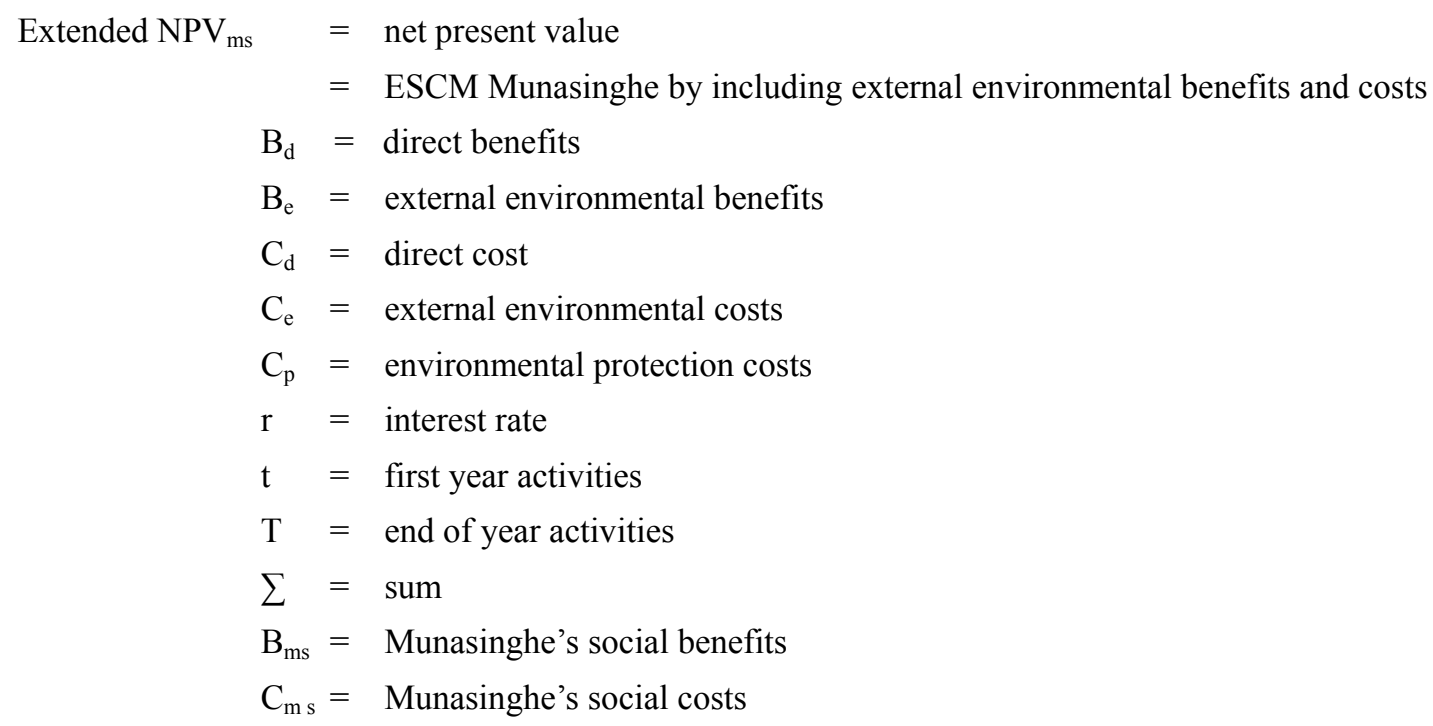

Development of an extended model of benefits and costs for ESCM is done by entering the elements above with the following steps:

1) Analysis of the benefits and costs of sustainable coal mining must identify the positive and negative externalities of the impacts of coal mining during the life of the mine and post-mining coal to environmental services, mine void water as raw water.

2) Categorize the impact of externalities into the analysis of the benefits and costs for ESCM as financial benefits and costs, environmental and community benefits and costs, as well as environmental services of mine void water for raw water for the life of the mine, as well as the benefits and costs of utilizing voids after coal mining.

3) Include financial benefits and costs components, external environmental benefits and costs, external benefits and costs of the community, and benefits and costs of raw water into the mathematical equation of the extended model of benefits and Munasinghe costs above (Equation 1).

The general model of extended mathematical equations of benefits and costs for ESCM as shown in Equation 2 below can be formulated and found by following the steps above.

$$
\begin{aligned}
\text { Extended NPV ba } & =\sum_{t=0}^{n} \frac{\left(B_{d}+B_{e}+B_{e m}+B_{a v}\right)}{(1+r)^{t}} \\
& -\sum_{t=0}^{n} \frac{\left(C_{d}+C_{e}+C_{e m}+C_{a v}\right)}{(1+r)^{t}}+\sum_{t=n+1}^{n+m} \frac{\left(B_{a v p c}+B_{e p c}+B_{e m p c}\right)}{(1+r)^{t}} \\
& -\sum_{t=n+1}^{n+m} \frac{\left(C_{a v p c}+C_{e p c}+C_{e m p c}\right)}{(1+r)^{t}}=\sum_{t=0}^{n+m} \frac{(B b a-C b a)}{(1+r)^{t}}
\end{aligned}
$$

Source: Juniah, 2013

where:

$$
\begin{aligned}
\text { Extended NPV } & =\text { Net Present Value } \\
= & \text { ESCM by including the value of environmental services, mine void } \\
& \text { water for raw water } \\
\mathrm{B}_{\mathrm{d}}= & \text { direct benefits. } \\
\mathrm{B}_{\mathrm{e}}= & \text { external environmental benefits. }
\end{aligned}
$$




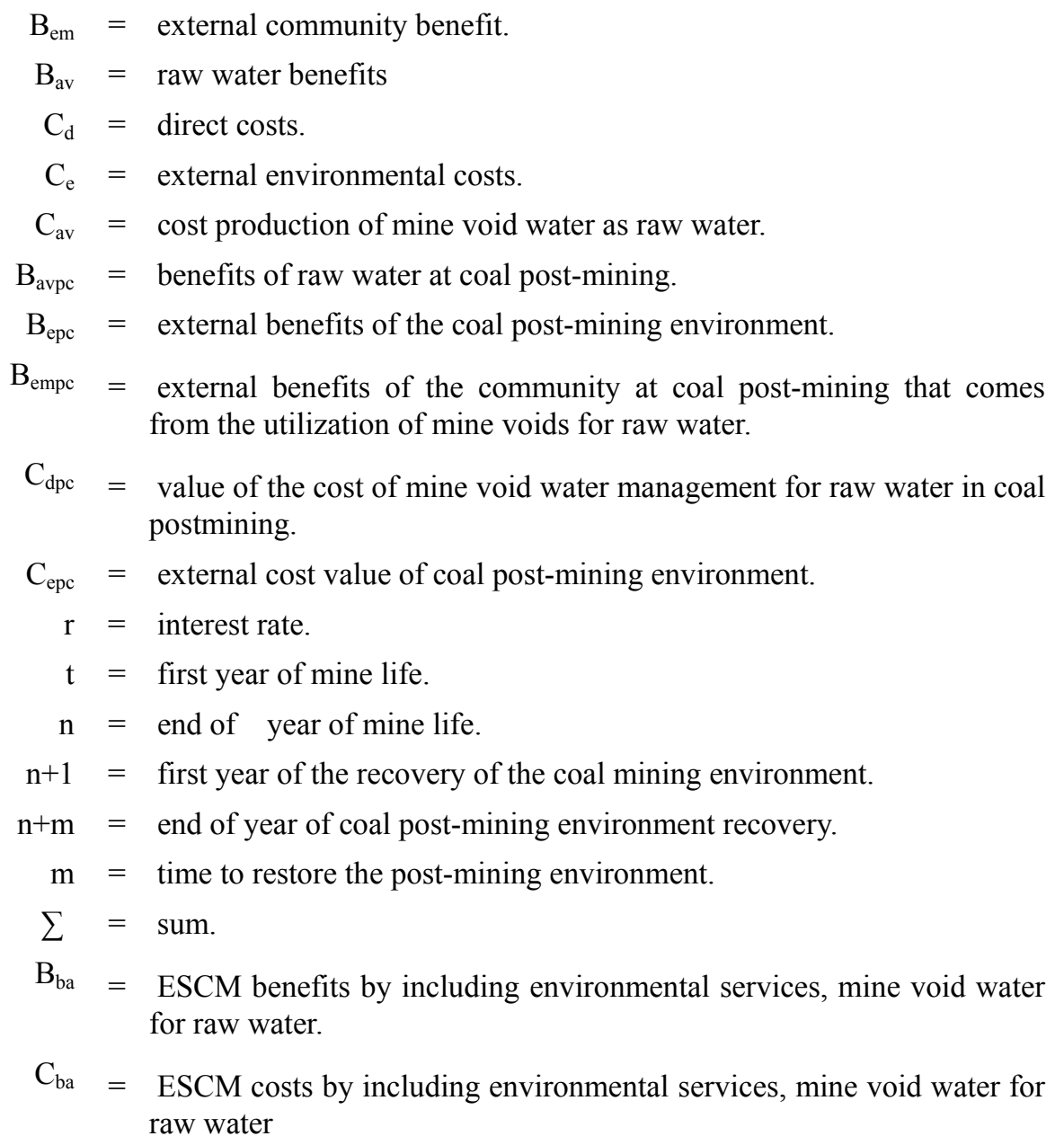

Components of benefits and costs as externalities of coal mining business activities against environmental services, and mine void water as raw water are included in the model of extended mathematical equation benefits and Munasinghe costs above (printed in red).

\section{Conclusion}

The final product of the analysis is the sustainability of the coal mining environment, can be used as an alternative solution for the conflict of interest between the activities of utilizing natural resources of coal in an open mine with environmental protection. The government and the usual business of coal mining not only take advantage of coal mining, but also must take into account the negative externalities that arise in environmental and community sustainability. Therefore the external benefits and costs arising from the environment and society must be integrated into the mathematical equation of the benefits and costs model. By integration of extending the extended Munasinghe model of benefits and costs. The benefits and costs that are integrated are the external costs of the environment, the external costs of the community, external benefits due to revegetation activities on former coal mining land, and the activities of utilizing acid mine drainage as raw water, into the mathematical equation of the extended model of benefits and Munasinghe costs.

The concept of model extended benefit and cost of environmental sustainability of coal mining can be applied by: 1) The Government, policy maker for the implementation of coal mining business activities as outlined in the feasibility study policy of coal mining business activities; 2) Common business of coal mining sector openly as a coal mining business actor in assessing the feasibility or sustainability of coal mining business activities; 3 ) mining investors through professional associations (PERHAPI/IMA), by asking the government to make the free prior informed consent of the local community, a pre-requisite of social license to operate.

\section{Acknowledgments}

Thanks to the management of PT Bukit Asam (Persero) Tbk for the opportunity given to the author to conduct a research survey on the location of the coal mining business permit of PT Bukit Asam (Persero) Tbk. 


\section{References}

Betani Anderlef, Sribudiani Evi, Mukhamadun. (2016). Economic Carbon Valuation In The Stands Level Poles And Trees At Forest For Special Purpose Jungle Training Bukit Suligi Regency Rokan Hulu. Jom Faperta UR Vol 3 No 2 Oktober 2016.

Dallaire, K., Skousen, J., \& Schuler, J. (2015). Height Of Three Hardwood Species Growing On Mine Sites Reclaimed Using The Forestry Reclamation Approach Compared To Natural Conditions. Journal American Society of Mining and Reclamation, 4(2), 20-35. https://doi.org/10.21000/JASMR15020020

Diwyastra, P. D., Moersidik, S. S., \& Soelarno, W. S. (2015). Cost Benefit of Water Use of Mine Void (Study at Postmining Void PT Multi Harapan Utama, Margahayu Village, Kutai Kertanegara Regency, East Kalimantan Province). Conference: International Conference On Social, Economics, And Culture, 2nd AICIE, 1st AICSP, 1st AICEDC (Annual International Conference on Economics in Developing Countries): "Developing Countries Readiness Towards Global Competition", At Surakarta Indonesia, Volume: Proceeding Book p.49.

Eugene, L. R., \& Singh, O. P. (2014). Degradation in Water Quality due to Limestone Mining in East Jaintia Hills,Meghalaya, India. International Research Journal of Environment Sciences, 3(5), 13-20.

Government Regulation Number 44 of 2017 concerning Environmental Economic Instruments.

Government Regulation Number 82 of 2001 concerning Management of Water Quality and Water Pollution.

Juniah, R. (2013). Environmental Sustainability Model of Coal Mining Study Value of Environmental Services, And Water Void Mine For Raw Water In PT Bukit Asam Tbk Tanjung Enim South Sumatra. Dissertation. Environmental Science Program University of Indonesia. Jakarta.

Juniah, R. (2017). Sustainable Mining Environment: Technical Review of Post-mining Plans. Indonesian Journal of Environmental Management and Sustainability.

Juniah, R. (2018a). Harmonization of Green Open Space as Carbon Similator for Suistable Environtment of Transportation Sector and Steam Power Plant. Journal Sriwijaya of Environtment, 3(1), 43-46. https://doi.org/10.22135/sje.2018.3.1.43-46

Juniah, R. (2018b). Study of Carbon Value of the Allotment of Former Coal Mining Land of PT Samantaka Batubara for Sustainable Mining Environment. Journal of Sustainable Development, 11(4). https://doi.org/10.5539/jsd.v11n4p213

Juniah, R., Dalimi, R., Suparmoko, M., \& Moersidik, S. S. (2013) Public Health Impact of Coal Mining Among Community Living in Coal Mining Area (Review on Environmental Benefits to Absorb Carbon). Jurnal Ekologi Kesehatan, 12(1), 252-258.

Juniah, R., Dalimi, R., Suparmoko, M., Moersidik, S. S., \& Waristian, H. (2016). Environmental Value Losses as Impacts of Natural Resources Utilization of in Coal Open Mining. Matec Proceding Scopus Index.

Kokko, K., Buanes, A., Koivurova, T., Masloboev, V., \& Pettersson, M. (2015). Sustainable Mining, Local Communities And Environmental Regulation. Barents Studies: Peoples, Economies And Politics, 2(1), 50 81

Law Number 32 of 2009 concerning Environmental Protection and Management, Ministry of Environment of the Republic of Indonesia, Jakarta.

Law Number 4 of 2009 concerning Mineral and Coal Mining. Ministry of Energy and Mineral Resources of the Republic of Indonesia, Jakarta.

Legwaila, I. A., Eckart, L., \& Cripps, J. (2015). Quarry Reclamation In England : A Review Of Techniques. Journal American Society of Mining and Reclamation, 4(2), 55-79. https://doi.org/10.21000/JASMR15020055

Moersidik, S. S. et al. (2014). Model of Water Resources Sustainability: Mining Void Water Utilization in Coal Mining (Case Study at PT. Adaro Indonesia, South Borneo, Indonesia). International Journal of Applied Engineering Research (IJAER), 9(9).

Munasinghe, M. (1992). Environmental Economics and Valuation in Development Decision Making. Environment Working Paper No.51, Environment Department, Sector Policy and Research Staff, The World Bank, Washington.

Sudirman Dadang. (2011). Optimization of Compensation Costs for Environmental Damage to Coal Mining 
Activities in Protected Forests. Doctoral Dissertation. University of Indonesia Environmental Sciences Program. Jakarta.

Suparmoko, M. (2006). Economic valuation guide \& analysis of natural and environmental resources: concepts, calculation methods, and applications. First Edisis, BPFE-Yogyakarta,

Taufik, T., \& Waluyo, M. B. (2017). Blasting design Without Subdrilling on Joint Limestone to Optimize Fragmentation and Blasting Cost. International Joernal on Advanced Science Engineering Information Technology, 7(5).

Turner, J. V., \& Jones, D. R. (1998). Final Void Water Quality in Australia Review - State of the art and development of a generic model, CSIRO Report 98-32, for Australian Center for Mining Environmental Research, May 1998.

\section{Copyrights}

Copyright for this article is retained by the author(s), with first publication rights granted to the journal.

This is an open-access article distributed under the terms and conditions of the Creative Commons Attribution license (http://creativecommons.org/licenses/by/4.0/). 